\title{
Fuel Cell Demonstration Program - Central and Remote Sites 2003
}

Final Report

April 24, 2003 to J une 30, 2006

Gerald Brun

September 2006

DOE Award No. DE-FG26-03NT42019

Long Island Power Authority

333 Earle Ovington Blvd

Uniondale, NY 11553 


\section{DISCLAIMER}

This report was prepared as an account of work sponsored by an agency of the United States Government. Neither the United States Government nor any agency thereof, nor any of their employees, makes any warranty, express or implied, or assumes any legal liability or responsibility for the accuracy, completeness, or usefulness of any information, apparatus, product, or process disclosed, or represents that its use would not infringe privately owned rights. Reference herein to any specific commercial product, process, or service by trade name, trademark, manufacturer, or otherwise does not necessarily constitute or imply its endorsement, recommendation, or favoring by the United States Government or any agency thereof. The views and opinions of authors expressed herein do not necessarily state or reflect those of the United States Government or any agency thereof. 


\begin{abstract}
In an effort to promote clean energy projects and aid in the commercialization of new fuel cell technologies, the Long Island Power Authority (LIPA) initiated a Fuel Cell Demonstration Program in 1999 with six month deployments of Proton Exchange Membrane (PEM) non-commercial Beta model systems at partnering sites throughout Long Island. These projects facilitated significant developments in the technology, providing operating experience that allowed the manufacturer to produce fuel cells that were half the size of the Beta units and suitable for outdoor installations.
\end{abstract}

In 2001, LIPA embarked on a large-scale effort to identify and develop measures that could improve the reliability and performance of future fuel cell technologies for electric utility applications and the concept to establish a fuel cell farm (Farm) of 75 units was developed. By the end of October of 2001, 75 Lorax 2.0 fuel cells had been installed at the West Babylon substation on Long Island, making it the first fuel cell demonstration of its kind and size anywhere in the world at the time.

Designed to help LIPA study the feasibility of using fuel cells to operate in parallel with LIPA's electric grid system, the Farm operated 120 fuel cells over its lifetime of over 3 years including 3 generations of Plug Power fuel cells (Lorax 2.0, Lorax 3.0, Lorax 4.5). Of these 120 fuel cells, 25 Lorax 4.5 units operated under this Award from April 2003 to December 2004.

In parallel with the operation of the Farm, LIPA recruited government, commercial, and residential customers to demonstrate fuel cells as on-site distributed generation. The deployment of the 20 Lorax 4.5 units for the Remote Sites phase of the project began in October 2004. To date, 10 fuel cells have completed their demonstrations while 10 fuel cells are currently being monitored at various customer sites throughout Long Island.

As of June 30, 2006 the 45 fuel cells operating under this Award produced a total of $1,585,093 \mathrm{kWh}$. As fuel cell technology became more mature, performance improvements included increases in system efficiency and availability. Including equipment, design, fuel, maintenance, installation, and decommissioning the total project budget was approximately $\$ 3.7$ million. 


\section{TABLE OF CONTENTS}

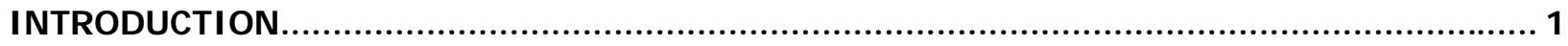

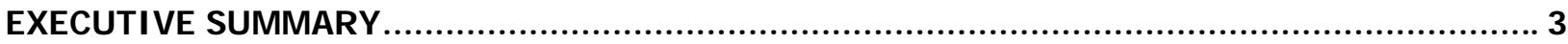

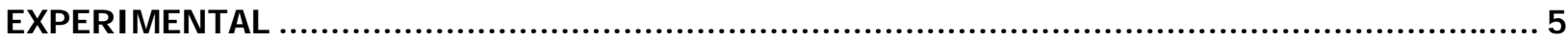

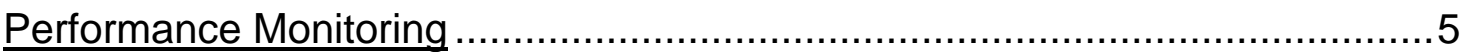

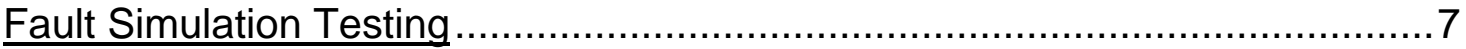

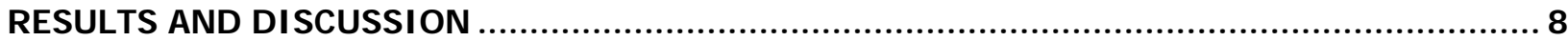

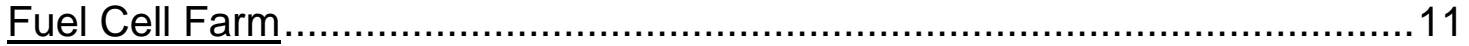

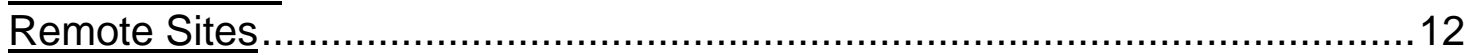

CONCLUSI ON............................................................................................................. 17

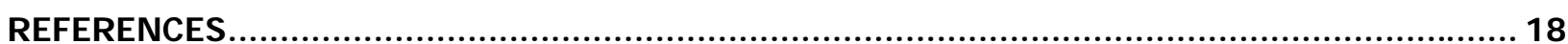




\section{LIST OF FI GURES}

Figure 1: COMSYS Website - Site Overall Performance ............................5

Figure 2: COMSYS Website - Individual Fuel Cell Performance........................6

Figure 3: Farm Fuel Cell Layout.................................................... 11

Figure 4: Fuel Cell Farm ................................................................. 11

Figure 5: Fuel Cell at 27 East Bay Dr. at Good Samaritan Hospital...................13

Figure 6: Fuel Cells at SUNY Farmingdale ........................................... 13 


\section{LIST OF TABLES}

Table 1: Lorax 4.5 Fuel Cell Specifications..................................................

Table 2: List of Lorax 4.5 SU1 Fuel Cells - Award No. DE-FG26-03NT42019 ....10

Table 3: Farm output for 25 Lorax 4.5 SU1 fuel cells.....................................11

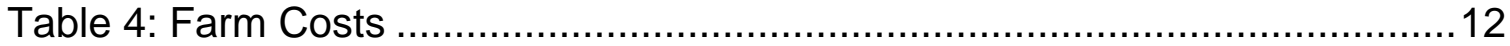

Table 5: Remote Sites Output for 20 Lorax 4.5 SU1 Fuel Cells........................14

Table 6: Average Energy Efficiency of Remote Sites.....................................15

Table 7: Average Maintenance Requirements .............................................15

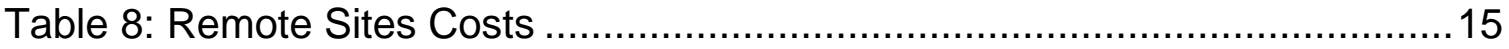




\section{INTRODUCTION}

Long Island Power Authority (LIPA) realizes the importance of looking towards the future. LIPA provides electricity to 1.1 million customers on Long Island, including Nassau, Suffolk, and the Rockaway Peninsula in Queens. As a result of this responsibility, LIPA is faced with continually increasing energy needs. While striving to provide reliable, cost-effective service to customers throughout its territory, LIPA has made environmental concerns one of its top priorities.

The Long Island Power Authority's comprehensive program, the Clean Energy Initiative (CEI), is one of the most ambitious programs of its kind. The CEI encompasses nearly a dozen energy conservation programs and cutting-edge research, development and demonstration (RD\&D) efforts. The Clean Energy Initiative is a ten year, \$355 million program, proposed by New York State Governor George Pataki, to foster the development and application of clean energy technologies, including fuel cells in LIPA territories.

LIPA's Fuel Cell Program (Program) began in 1999 as part of the CEI. The Program shares its objective of furthering commercialization of fuel cell power generators to reduce greenhouse gas emissions with the "2003 Climate Change Fuel Cell Program" of the Department of Defense. This commonality has facilitated LIPA to receive financial support to supplement its Program through two awards funded through the Department of Energy's National Energy Technology Laboratory (NETL).

At the beginning of its Program LIPA partnered with Plug Power to demonstrate fuel cell systems' operational characteristics. The partnership emphasized learning and increased benefit to LIPA, its customers, and the evolving technology. Plug Power fuel cells were sold to LIPA under an agreement that included training, engineering services, and technical support to operate and maintain the units. The fuel cell systems (FCS) were fully integrated to include a fuel processor, a fuel cell stack, and an inverter. The FCS's were designed to generate up to $5 \mathrm{~kW}$ with a nominal voltage of $240 \mathrm{~V}$ at $60 \mathrm{~Hz}$. Fueled by natural gas, the FCS produced very low emissions and low noise. While their operating temperature ranged from $255^{\circ} \mathrm{K}$ to $313^{\circ} \mathrm{K}$, the FCS's were not designed for waste heat utilization.

In 2000, planning started for the construction of the Long Island Fuel Cell Farm. In 2001, LIPA constructed a 3-acre fuel cell site adjacent to the West Babylon substation. The operation and support of the fuel cell farm required the training of a local service provider. Through competitive bidding, Elemco of Bohemia, NY was selected. Elemco has since then become a valuable partner in the deployment of fuel cell technology throughout Long Island. Elemco's technicians were trained by Plug Power for the operation and maintenance of the fuel cells.

The West Babylon Farm site provided the initial platform for LIPA's Fuel Cell Demonstration program. The site was built to support the operation of $755 \mathrm{~kW}$ 
fuel cells. In addition, this operation would determine grid impacts of large concentrations of fuel cells on the distribution grid.

The initial phase of fuel cell deployments for distributed generation at remote sites started in parallel with the Farm project. This Remote Sites phase began with an installation in July 2002 and progressed along the same lines as the Farm by testing newer fuel cell technologies as they were made available. Indeed, 20 Lorax 4.5 (Gensys 5CS) were identified for testing at 16 selected sites on Long Island including: 3 residences at Good Samaritan Hospital, 7 residences at Winthrop University Hospital, International Brotherhood of Electrical Workers (IBEW) Local\#25, Town of Hempstead Animal Shelter, Babylon Town Hall, Suffolk County Legislature, SUNY Farmingdale, and Richner Communications. Per the site agreements with these customers, any cost of natural gas consumed by the fuel cells in excess of the value of the electric output and that of the heat output of these fuel cells based on LIPA's electric rate are to be reimbursed by LIPA. This cost is referred to as the True-Up cost.

A list of the 45 Lorax 4.5 FCS and their locations is listed in Table 2. 


\section{EXECUTIVE SUMMARY}

In 1999 LIPA began its Fuel Cell Program as part of its Clean Energy Initiative Program which works with customers, equipment manufacturers, and the energy marketplace to promote energy conservation and clean energy technologies to reduce greenhouse gas emissions. By partnering with Plug Power in 1999 to begin testing and demonstrating fuel cell power plants, LIPA began its effort to support the commercialization of the technology. Originally, 6 Beta model systems were installed at 4 laboratories of partnering sites including Brookhaven National Laboratories, Hofstra University, US Merchant Marine Academy, and State University of NY at Stony Brook. This initiative facilitated several technology advances such as significant reductions in equipment size and costs.

With the lessons learned and developments of the units from Plug Power, LIPA embarked on a multi-million dollar fuel cell demonstration Fuel Cell Farm project focusing on increasing its energy supply to meet the growing energy demands on Long Island without noticeably increasing its greenhouse gas emissions.

From 2001 to 2004, LIPA installed and demonstrated 120 fuel cell systems (FCS) at the Farm in West Babylon, NY. The first phases of the Farm consisted of testing 75 Lorax 2.0 fuel cell systems (FCS) and 20 Lorax 3.0 units. To support further design improvements, 25 FCS of the following generation, Lorax 4.5, were tested as part of the third and last phase from April 2003 to December 2004.

In parallel to the Farm project, LIPA continued the deployment of the newer fuel cell technology at Remote Sites. From October 2004 to June 2005, 20 Lorax 4.5 FCS were sited for distributed generation applications at residential, commercial, and government facilities. Each unit operated in parallel to the grid for a minimum period of 12 months supplying power to the facilities and reducing their dependencies on the utility grid. These FCS equipped with a recovered heat output enabled the supply of thermal heat by tying in the heat output to the facility's water heating system. An additional application to isolate critical loads to which the fuel cells would provide power in moments of grid outages was identified for the fuel cells at all residential sites, at Suffolk County Legislature, at IBEW Local \#25, and at Richner Communications.

Systems developed by the FCS manufacturer and a third-party consultant enabled near real-time monitoring of all FCS. These systems monitored key performance parameters while providing alarm notifications when units shut down. Underwriters Laboratories (UL) was appointed for designing and conducting fault simulation tests on the utility interactive fuel cell systems located at the Farm in West Babylon.

The 45 Lorax 4.5 FCS operated under this Award produced a total of 1,585,093 $\mathrm{kWh}$ during the reporting period. The mean time between failures for these FCS was 1,258 hours (52 days). These units were available and operating $65 \%$ of 
their operational terms with an overall energy efficiency of $38.95 \%$ including electrical and thermal efficiencies. As fuel cell technology changed with the introduction of next generation units, improvements in fuel cell technology for distributed generation included increases in availability and system efficiency. Including equipment, design, fuel, maintenance, and testing, the total project budget was approximately $\$ 3.8$ million. The resulting cost of the project was \$2.44 per kWh. 


\section{EXPERIMENTAL}

\section{Performance Monitoring}

In order to capture performance data, two monitoring systems were used for all fuel cells: Plug Data Warehouse, and Connected Energy Corporation Central Operation Management System (COMSYS). The COMSYS interface was webbased - sample information is provided in Figure 1 and Figure 2. Key parameters captured from either/or both monitoring systems included:

- Average Electric Output

- kWh Energy Output

- Electrical Efficiency

- Site Availability

- Fuel Usage

- Capacity Factor

- Availability

- Heat Recovery

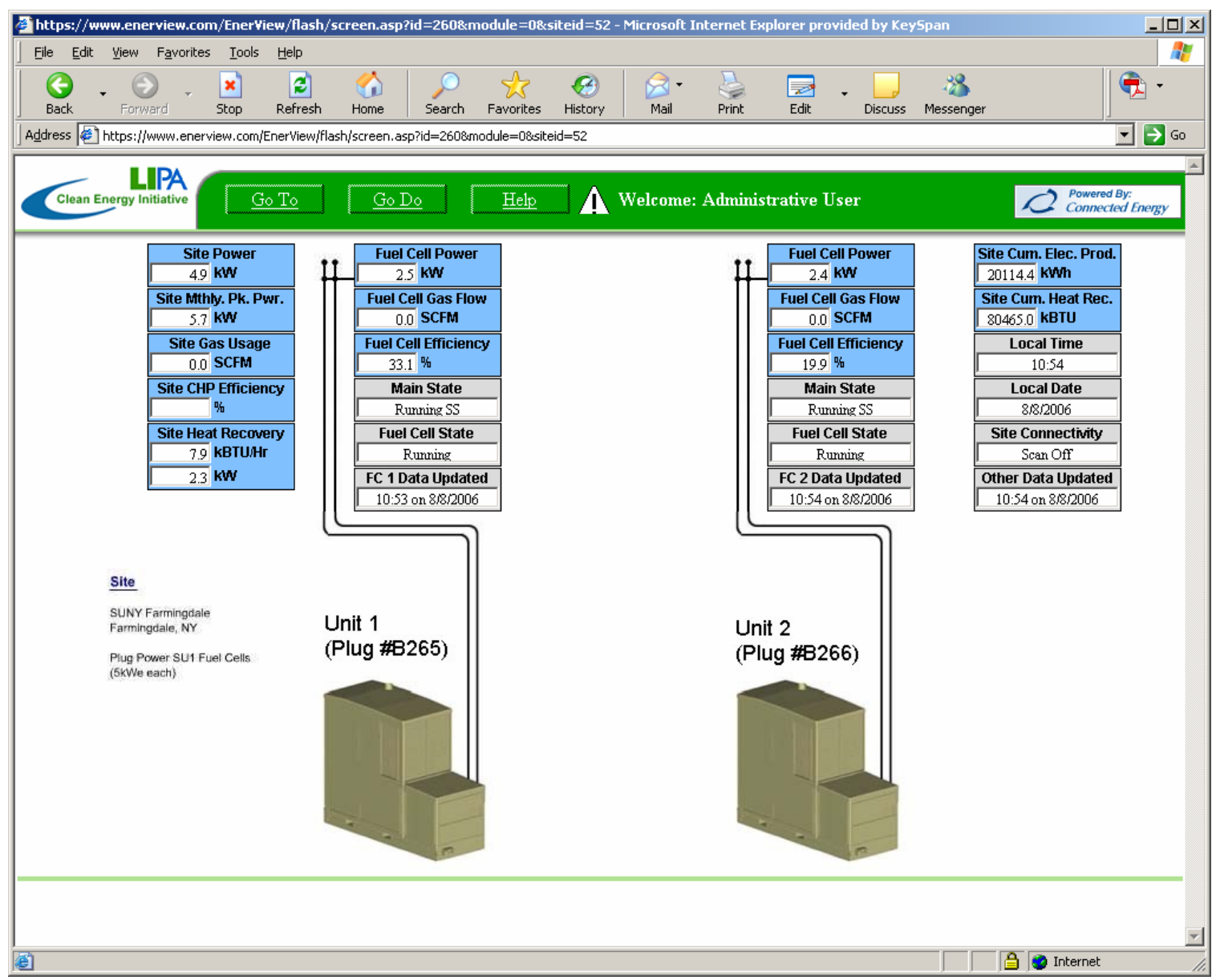

Figure 1: COMSYS Website - Site Overall Performance 


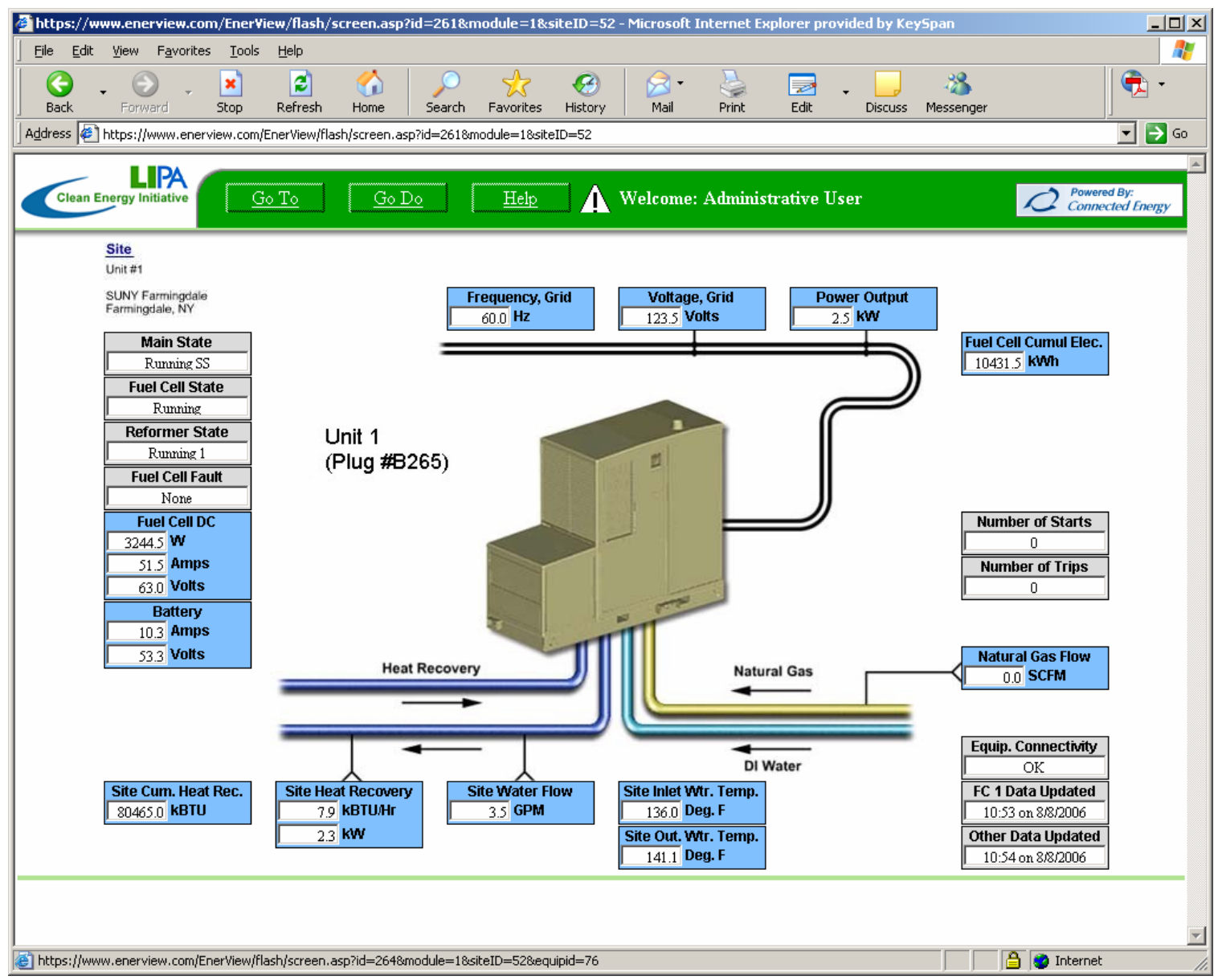

Figure 2: COMSYS Website - Individual Fuel Cell Performance

The Lorax 4.5 is designed to automatically send operational data (sampled every 10 minutes) once per day, via modem/dial-up connection, to Plug Power. Once at Plug Power, the data is entered into the Data Warehouse database. Furthermore, during every system shutdown, the unit automatically reports to Plug Power its status, error logs and high-speed data. The high-speed data is a packet of data-points taken at a much higher resolution (every second for the last 10 minutes). This information is used to track preventative maintenance items, troubleshoot failures, and dispatch field service technicians. Complete system operational data can also be downloaded directly from the machine by a trained service technician with a laptop and RS232 connection cable.

Additionally, through the Connected Energy's COMSYS, data points were collected via a remote monitoring cabinet using Modbus protocol for communication with the fuel cells. Data was transmitted back to Connected Energy via a phone line with DSL service. A secured website was developed by Connected Energy to report near real-time (5-15 seconds) parameters and alarms near real-time (Figure 1, Figure 2). This information was also used for maintenance purposes and to dispatch service technicians in the case of a communication failure with the fuel cell integrated monitoring system. 


\section{Fault Simulation Testing}

The Fuel Cell Farm project was the first of its size when it started in 2001, and laboratory testing of fuel cells for interfacing with utility systems was limited. As part of this project, LIPA appointed Underwriters Laboratories (UL) to design, simulate and perform fault simulation testing on the utility interactive fuel cell systems located at the Farm in West Babylon. The goal of this endeavor was to gain knowledge on how large numbers of utility interactive distributed generation units - in this case fuel cell systems would respond to real world utility faults.

The fault simulation was setup in 3 phases: Test Development, Software Modeling, and Field Test. Once the existing system at the Farm was analyzed, a test plan was developed. Computer simulation software was then designed to analyze the results and finalize the test plan.

The field tests began on August 16, 2004 and lasted for 3 days. Fifteen (15) fuel cell systems on site were chosen for the test. Each unit contained the MP 5000 Utility Interactive Inverter. The testing consisted of measuring precise time based voltage and current at several nodes throughout the site for various fault scenarios including simulated islanding conditions. The testing apparatus included 3 synchronized power analyzers capable of recording and measuring multiple voltage and current input channels.

The results of the UL testing can be found in the Results and Discussion section on Page 12. 


\section{RESULTS AND DISCUSSION}

The 45 FCS listed in Table 2 were fueled by natural gas. Though they were designed to supply up to $5 \mathrm{~kW}$ of power, their output were set at $2.5 \mathrm{~kW}$ during normal operation. At the Farm, the FCS were connected to the utility grid, and at the Remote Sites they operated in parallel to the grid supplying power to the facilities.

In addition to the parallel configuration of the FCS at all the Remote Sites, the fuel cells were operated isolated from the grid and supplied electricity to identified critical loads of the facilities during events of electric outages. The critical load application was only setup for the following sites: Good Samaritan Hospital residences, Winthrop-University Hospital residences, IBEW Local \#25, and Suffolk County Legislature. The identification of critical loads was performed by the utility, the original equipment manufacturer, the service contractor, and the host facility. These loads were isolated by installing a critical load panel in addition to the main panel of the facility. Typical loads identified at residences included refrigerators, heating systems, bathroom and living room outlets, and lighting. Loads identified at commercial-type customers included alarm systems, lighting, and heating systems.

The fuel cell systems sited for this phase of the Remote Sites enabled the capability for heat recovery. One of the primary goals of this phase of the Fuel Cell Program was to demonstrate and test the heat recovery application of fuel cells. Indeed, all Remote Sites fuel cell systems operated as combined heat and power (CHP) systems. In addition to the electric installation, the heat generated from the fuel cells was combined with the facility's water heating system via a heat recovery system containing glycol and therminol.

Table 1 lists the Lorax 4.5 target specifications. 
Table 1: Lorax 4.5 Fuel Cell Specifications

\begin{tabular}{|c|c|c|c|}
\hline Attribute & \multicolumn{3}{|c|}{ Specification } \\
\hline Type of Fuel Cell & \multicolumn{3}{|c|}{ Proton Exchange Membrane (PEM) } \\
\hline Model & \multicolumn{3}{|c|}{ GenSys $^{\text {TM }}$ 5CS (Lorax 4.5) } \\
\hline Power Output & \multicolumn{3}{|l|}{$2.5-5 \mathrm{~kW}$} \\
\hline Manufacturer & \multicolumn{3}{|c|}{ Plug Power Inc., Latham, New York } \\
\hline Unit Size & \multicolumn{3}{|c|}{ Base Unit with integral skid: $74 " \mathrm{~L}$ x 32 "W x 68 1/4"H } \\
\hline Installation Location & \multicolumn{3}{|c|}{ Outdoor } \\
\hline Grid Parallel & \multicolumn{3}{|l|}{ Yes } \\
\hline Standby Capability & \multicolumn{3}{|c|}{$\begin{array}{l}\text { Maximum Load }-4.5 \mathrm{~kW}, 400 \text { hours per year of operation } \\
\text { independent of the electric grid. }\end{array}$} \\
\hline Remote monitoring capability & \multicolumn{3}{|c|}{ Via phone line or RS232 } \\
\hline Output Voltage & \multicolumn{3}{|c|}{$\begin{array}{l}120 \text { VAC @ } 60 \mathrm{~Hz} \text {. Can be adapted to other standard voltages } \\
\text { such as } 240 \mathrm{~V} \text { or } 480 \mathrm{~V} \text {. }\end{array}$} \\
\hline Certification & \multicolumn{3}{|c|}{ Integrated System CSA International Certified; Inverter UL Listed } \\
\hline Waste Heat Utilization & \multicolumn{3}{|c|}{$\begin{array}{l}\text { Yes. System Efficiency will vary depending on external } \\
\text { cogeneration loop temperature and flow rate. Based on the } \\
\text { published overall system efficiencies of } 60 \%, 65 \% \text {, and } 55 \% \text {, the } \\
\text { minimum thermal energy output of } 3270 \mathrm{~W}, 6400 \mathrm{~W} \text {, and } 6700 \mathrm{~W} \\
\text { should be expected for } 2.5,4 \text {, and } 5 \mathrm{KW} \text { setpoints respectively. }\end{array}$} \\
\hline Recovered heat output & \multicolumn{3}{|c|}{$\begin{array}{l}\text { - Heat Recovery Liquid Operating Pressure } \\
\text { Range } 0-50 \text { PSIG } \\
\text { - Heat Recovery Liquid Temperature } \\
\text { Range } 32^{\circ} \mathrm{F} \text { to } 130^{\circ} \mathrm{F} \\
\text { - Expected Heat Recovery Liquid Flow } \\
\text { Range } 0 \text { to } 10 \text { GPM } \\
\text { - Customer Fluid Connections to Fuel Cell } \\
3 / 4^{\prime \prime} N P T \text { Female }\end{array}$} \\
\hline Electric only efficiency & \multicolumn{3}{|c|}{$\begin{array}{l}26 \% @ 2.5 \mathrm{~kW} \\
25 \% @ 4.0 \mathrm{~kW} \\
23.5 \% \text { @W }\end{array}$} \\
\hline Overall efficiency (with CHP) & \multicolumn{3}{|c|}{$\begin{array}{l}60 \% @ 2.5 \mathrm{~kW} \\
65 \% @ 4.0 \mathrm{~kW} \\
55 \% @ 5 \mathrm{~kW}\end{array}$} \\
\hline Fuel capability & \multicolumn{3}{|c|}{ Natural gas \& Propane } \\
\hline Fuel use (Natural Gas) & \multicolumn{3}{|c|}{$\begin{array}{l}\text { Gas requirements are as follows: minimum of } 70 \text { standard liters } \\
\text { per minute (SLM) of natural gas. Natural gas constituency must } \\
\text { be }>90 \% \text { methane and sulfur content no greater than } 15 \mathrm{ppm} \text { on a } \\
\text { yearly average basis. Projected fuel consumption (MMBtus) at } \\
\text { rated electric power, and electrical efficiency at peak and part-load } \\
\text { conditions }\end{array}$} \\
\hline & Power (kW) & Efficiency (\%) & Fuel use (BTUs/hour) \\
\hline & 2.5 & 26 & 31,600 BTUs \\
\hline & 4 & 25 & 54,600 BTUs \\
\hline & & 23.5 & 73,000 BTUs \\
\hline & $\begin{array}{l}\text { Fresh water } \\
\text { gpd, } 136 \mathrm{~g} \\
\text { power level }\end{array}$ & $\begin{array}{l}\text { ply is requirec } \\
\text { and } 176 \text { gpd } \\
\text { spectively. }\end{array}$ & $\begin{array}{l}\text { System requires approximately } 80 \\
\text { f fresh water at } 2.5,4 \text {, and } 5 \mathrm{~kW}\end{array}$ \\
\hline
\end{tabular}


Table 2: List of Lorax 4.5 SU1 Fuel Cells - Award No. DE-FG26-03NT42019

\begin{tabular}{|c|c|c|c|c|}
\hline Serial \# & $\begin{array}{l}\text { Date of } \\
\text { Purchase }\end{array}$ & $\begin{array}{l}\text { Commission } \\
\text { Date }\end{array}$ & $\begin{array}{l}\text { 12-month } \\
\text { Completion Date }\end{array}$ & Location \\
\hline SU1000000209 & $2 / 25 / 2003$ & $4 / 24 / 2003$ & $4 / 24 / 2004$ & West Babylon Substation \\
\hline SU1000000210 & $2 / 25 / 2003$ & $4 / 25 / 2003$ & $4 / 25 / 2004$ & West Babylon Substation \\
\hline SU1000000211 & $2 / 25 / 2003$ & $4 / 25 / 2003$ & $4 / 25 / 2004$ & West Babylon Substation \\
\hline SU1000000212 & $2 / 25 / 2003$ & $5 / 2 / 2003$ & $5 / 2 / 2004$ & West Babylon Substation \\
\hline SU1000000213 & $2 / 25 / 2003$ & $5 / 2 / 2003$ & $5 / 2 / 2004$ & West Babylon Substation \\
\hline SU1000000214 & $2 / 25 / 2003$ & $5 / 2 / 2003$ & $5 / 2 / 2004$ & West Babylon Substation \\
\hline SU1000000215 & $2 / 25 / 2003$ & $5 / 2 / 2003$ & $5 / 2 / 2004$ & West Babylon Substation \\
\hline SU1000000216 & $2 / 25 / 2003$ & $5 / 2 / 2003$ & $5 / 2 / 2004$ & West Babylon Substation \\
\hline SU1000000217 & $2 / 25 / 2003$ & $5 / 4 / 2003$ & $5 / 4 / 2004$ & West Babylon Substation \\
\hline SU1000000218 & $2 / 25 / 2003$ & $5 / 4 / 2003$ & $5 / 4 / 2004$ & West Babylon Substation \\
\hline SU1000000219 & $2 / 25 / 2003$ & $5 / 5 / 2003$ & $5 / 5 / 2004$ & West Babylon Substation \\
\hline SU1000000220 & $2 / 25 / 2003$ & $5 / 13 / 2003$ & $5 / 13 / 2004$ & West Babylon Substation \\
\hline SU1000000221 & $2 / 25 / 2003$ & $6 / 3 / 2003$ & $6 / 3 / 2004$ & West Babylon Substation \\
\hline SU1000000222 & $2 / 25 / 2003$ & $5 / 13 / 2003$ & $5 / 13 / 2004$ & West Babylon Substation \\
\hline SU1000000223 & $2 / 25 / 2003$ & $5 / 16 / 2003$ & $5 / 16 / 2004$ & West Babylon Substation \\
\hline SU1000000224 & $2 / 25 / 2003$ & $5 / 15 / 2003$ & $5 / 15 / 2004$ & West Babylon Substation \\
\hline SU1000000225 & $2 / 25 / 2003$ & $5 / 15 / 2003$ & $5 / 15 / 2004$ & West Babylon Substation \\
\hline SU1000000226 & $2 / 25 / 2003$ & $5 / 16 / 2003$ & $5 / 16 / 2004$ & West Babylon Substation \\
\hline SU1000000227 & $2 / 25 / 2003$ & $5 / 16 / 2003$ & $5 / 16 / 2004$ & West Babylon Substation \\
\hline SU1000000228 & $2 / 25 / 2003$ & $5 / 16 / 2003$ & $5 / 16 / 2004$ & West Babylon Substation \\
\hline SU1000000229 & $2 / 25 / 2003$ & $5 / 19 / 2003$ & $5 / 19 / 2004$ & West Babylon Substation \\
\hline SU1000000230 & $2 / 25 / 2003$ & $5 / 20 / 2003$ & $5 / 20 / 2004$ & West Babylon Substation \\
\hline SU1000000232 & $2 / 25 / 2003$ & $5 / 20 / 2003$ & $5 / 20 / 2004$ & West Babylon Substation \\
\hline SU1000000233 & $2 / 25 / 2003$ & $5 / 20 / 2003$ & $5 / 20 / 2004$ & West Babylon Substation \\
\hline SU1000000234 & $2 / 25 / 2003$ & $5 / 21 / 2003$ & $5 / 21 / 2004$ & West Babylon Substation \\
\hline SU1000000231 & $2 / 25 / 2003$ & $1 / 29 / 2005$ & $1 / 29 / 2006$ & Winthrop - 61 5th Ave \\
\hline SU1000000235 & $2 / 25 / 2003$ & $12 / 23 / 2004$ & $12 / 23 / 2005$ & Winthrop - 58 6th Ave \\
\hline SU1000000236 & $2 / 25 / 2003$ & $12 / 23 / 2004$ & $12 / 23 / 2005$ & Winthrop - 64 6th Ave \\
\hline SU1000000237 & $2 / 25 / 2003$ & $12 / 23 / 2004$ & $12 / 23 / 2005$ & Winthrop - 68 6th Ave \\
\hline SU1000000238 & $2 / 25 / 2003$ & $1 / 14 / 2005$ & $1 / 14 / 2006$ & Winthrop - 5 Station Rd \\
\hline SU1000000254 & $2 / 25 / 2003$ & $1 / 14 / 2005$ & $1 / 14 / 2006$ & Winthrop - 6 Station Rd \\
\hline SU1000000255 & $2 / 25 / 2003$ & $1 / 29 / 2005$ & $1 / 29 / 2006$ & Winthrop - 8 Station Rd \\
\hline SU1000000256 & $2 / 25 / 2003$ & $10 / 13 / 2004$ & $10 / 13 / 2005$ & Good Sam. - 17 E. Bay \\
\hline SU1000000257 & $2 / 25 / 2003$ & $10 / 13 / 2004$ & $10 / 13 / 2005$ & Good Sam. - 23 E. Bay \\
\hline SU1000000258 & $2 / 25 / 2003$ & $10 / 13 / 2004$ & $10 / 13 / 2005$ & Good Sam. - 27 E. Bay \\
\hline SU1000000259 & $2 / 25 / 2003$ & $2 / 17 / 2005$ & $2 / 17 / 2006$ & Hempstead Animal Shelter \\
\hline SU1000000260 & $2 / 25 / 2003$ & $3 / 8 / 2005$ & $3 / 8 / 2006$ & IBEW - Local \#25 \\
\hline SU1000000261 & $2 / 25 / 2003$ & $5 / 12 / 2005$ & $5 / 12 / 2006$ & Babylon Town Hall \\
\hline SU1000000262 & $2 / 25 / 2003$ & $6 / 1 / 2005$ & $6 / 1 / 2006$ & Suffolk County Legislature \\
\hline SU1000000263 & $2 / 25 / 2003$ & $6 / 1 / 2005$ & $6 / 1 / 2006$ & Suffolk County Legislature \\
\hline SU1000000264 & $2 / 25 / 2003$ & $6 / 1 / 2005$ & $6 / 1 / 2006$ & Suffolk County Legislature \\
\hline SU1000000265 & $2 / 25 / 2003$ & $12 / 7 / 2005$ & $12 / 7 / 2006$ & SUNY Farmingdale \\
\hline SU1000000266 & $2 / 25 / 2003$ & $12 / 7 / 2005$ & $12 / 7 / 2006$ & SUNY Farmingdale \\
\hline SU1000000267 & $2 / 25 / 2003$ & $\mathrm{~N} / \mathrm{A}$ & $\mathrm{N} / \mathrm{A}$ & Richner Communications \\
\hline SU1000000268 & $2 / 25 / 2003$ & $\mathrm{~N} / \mathrm{A}$ & $\mathrm{N} / \mathrm{A}$ & Richner Communications \\
\hline
\end{tabular}




\section{Fuel Cell Farm}

The initial deployment in October 2001 of 75 units represented a micro-grid of 75 homes connected to A, B, and C phases of the distribution grid. While each FCS is designed to supply $240 \mathrm{~V}$ at $60 \mathrm{~Hz}$, the Farm layout and electrical work was designed to supply power to the grid on all 3 phases. At that time, this project represented the largest deployment of fuel cells in the world. Through the course of the project, the Farm was repopulated several times with newer generations of fuel cell technology including the 25 units identified under this Award. Figure 3 and Figure 4 show how the fuel cells were physically setup at the Farm.

These 25 Lorax 4.5 systems were installed in 2003 and operated until the end of 2004.

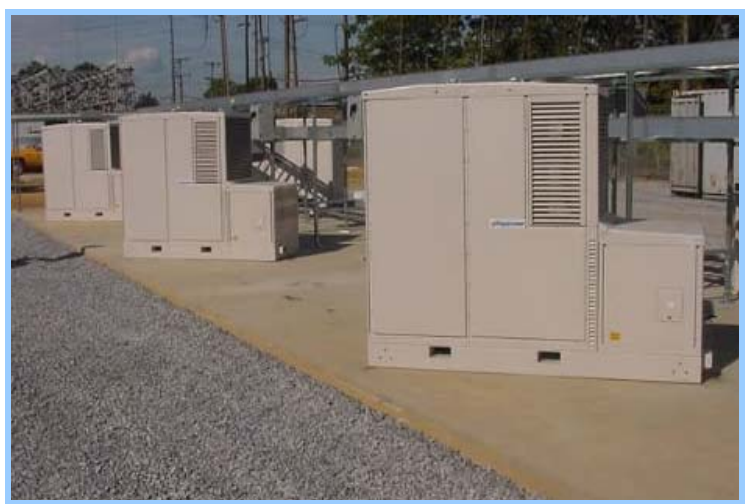

Figure 3: Farm Fuel Cell Layout

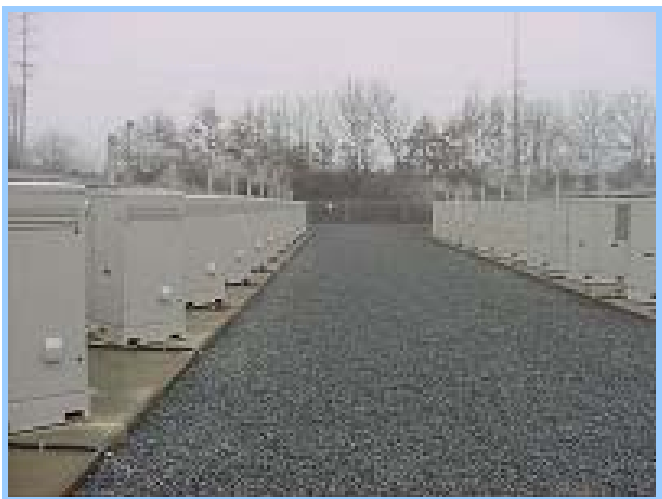

Figure 4: Fuel Cell Farm

The table below summarizes the combined performance figures for the Farm's Lorax 4.5 fuel cells over their operational life.

Table 3: Farm output for 25 Lorax 4.5 SU1 fuel cells

\begin{tabular}{|l|c|c|c|c|r|r|}
\hline & Serial \# & $\begin{array}{c}\text { Run } \\
\text { Hours }\end{array}$ & $\begin{array}{c}\text { Average } \\
\text { Elec. } \\
\text { Output }\end{array}$ & $\begin{array}{c}\text { Electrical } \\
\text { Efficiency }\end{array}$ & Availability & Energy Output \\
\hline $\begin{array}{l}\text { Farm - Lorax } \\
4.5\end{array}$ & $\begin{array}{l}\text { (refer to } \\
\text { Table 2) }\end{array}$ & 282,088 & $2.45 \mathrm{~kW}$ & $24.6 \%$ & $80.71 \%$ & $1,227,609 \mathrm{kWh}$ \\
\hline
\end{tabular}

The Lorax 4.5 generations of fuel cells at the Farm were operational $80.71 \%$ of the time for a total of about 282,088 hours. The average electrical efficiency was $24.6 \%$, an increase of $1 \%$ over the average of the 95 fuel cells previously tested at the Farm. Each Lorax 4.5 unit produced on average 49.1 MWhrs of energy with an average output was $2.45 \mathrm{~kW}$.

In general, the Lorax 2.0 and 3.0 units were similar in their performance. However, the performance of the Lorax 4.5 units stands out with an increase in availability of approximately $15 \%$ over the previous 2 generations. The higher 
run-time and higher electric output of the 25 Lorax 4.5 units resulted in a very significant energy production from these fuel cells.

In August 2004, the UL fault simulation testing took place parallel with the performance monitoring of the fuel cells. Fifteen (15) units were tested for various fault conditions including islanding conditions caused by inadvertent or maintenance operation of the distribution feeder breaker or recloser, and various service break scenarios. Results and findings from these simulations include the following:

- The exposure to islanding conditions does not seem to increase when many small single phase inverter-based distributed resource units are operated in conjunction with typical facility transformers. It was extremely difficult to create an island even when the inverter anti-islanding scheme was disabled.

- Unlike previously thought, high Q (ratio of inductive reactance to real power in the island) resonant circuits are not necessary to create an island. The tests showed that an islanding load with a $\mathrm{Q}$ as low as 0.5 could still support an island, given that the inverter's anti-islanding scheme was disabled. This finding was used in writing the recently approved "IEEE Standard 1547.1-2005 Conformance Test Procedures for Equipment Interconnecting Distributed Resources with Electric Power Systems" for standard laboratory testing requirements.

The Lorax 4.5 Farm project produced $1,227,609 \mathrm{kWh}$ and cost a total of $\$ 2,068,946$ (Table 4); resulting in an overall project cost of $\$ 1.69$ per $\mathrm{kWh}$. The combined energy output of the 25 units at the Farm accounted for an emission savings of $902 \mathrm{~kg}(1,988 \mathrm{lbs})$ of $\mathrm{SO}_{2}, 283 \mathrm{~kg}(625 \mathrm{lbs})$ of $\mathrm{NO}_{\mathrm{x}}$, and 48,488 kg $(106,897 \mathrm{lbs})$ of $\mathrm{CO}_{2}$.

\begin{tabular}{|l|l|l|l|l|l|}
\hline Site & $\begin{array}{l}\text { Equipment/ } \\
\text { Installation }\end{array}$ & $\begin{array}{l}\text { Maintenance } \\
\text { /Service }\end{array}$ & Fuel & Decommissioning & Total \\
\hline $\begin{array}{l}\text { Farm } \\
(25 \text { units })\end{array}$ & $\$ 1,400,000$ & $\$ 485,725$ & $\$ 123,826$ & $\$ 59,395$ & $\$ 2,068,946$ \\
\hline
\end{tabular}

Table 4: Farm Costs

The construction and maintenance of the Farm has provided unique opportunities for working in partnership with local governments, equipment suppliers, manufacturers, the U.S. Department of Energy, and foreign entities. The Farm site provided a test bed for LIPA and the utility industry to investigate the critical issues related to distributed generation plants.

$\underline{\text { Remote Sites }}$

The Lorax 4.5 phase of the Remote Sites deployment of fuel cells began in October 2004 with the first residential installations of the Fuel Cell Program at 3 
residences of Good Samaritan Hospital in Mineola (residential-rate customers, Figure 5). This installation was followed by 15 others at various commercial, government and other residential customers on Long Island including 2 at Nold Hall (gymnasium facility) at SUNY Farmingdale (Figure 6) - a complete list of sites is included in Table 2. All systems operated for a period of 12 to 18 months. Two fuel cell systems were allocated for testing at Richner Communications with the approach to install the units on the roof of the newly constructed building and integrate the systems with the building's design; thus not requiring any retrofit efforts. Due to the extended building construction time, the testing of these units has not been completed and their performance data is not included in this report.

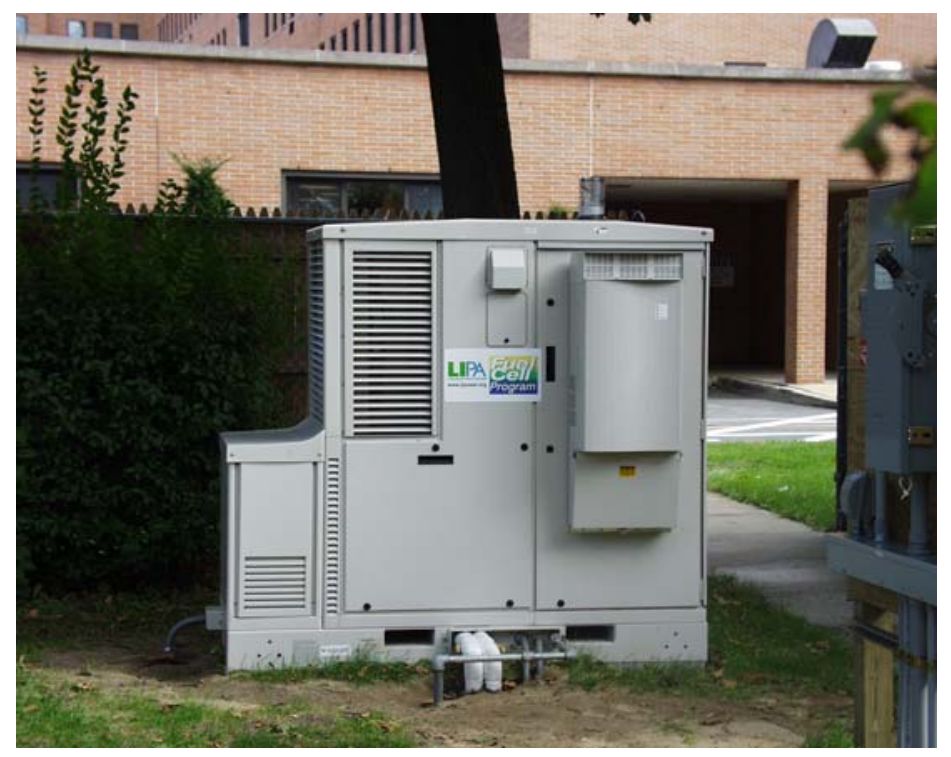

Figure 5: Fuel Cell at 27 East Bay Dr. at Good Samaritan Hospital

All 20 of the remote sites fuel cells were Gensys SU1 units or Lorax 4.5 systems, same as the Farm's units. Significant improvements in Lorax 4.5 technology include increases in electrical efficiency, availability, and the addition of thermal efficiency.

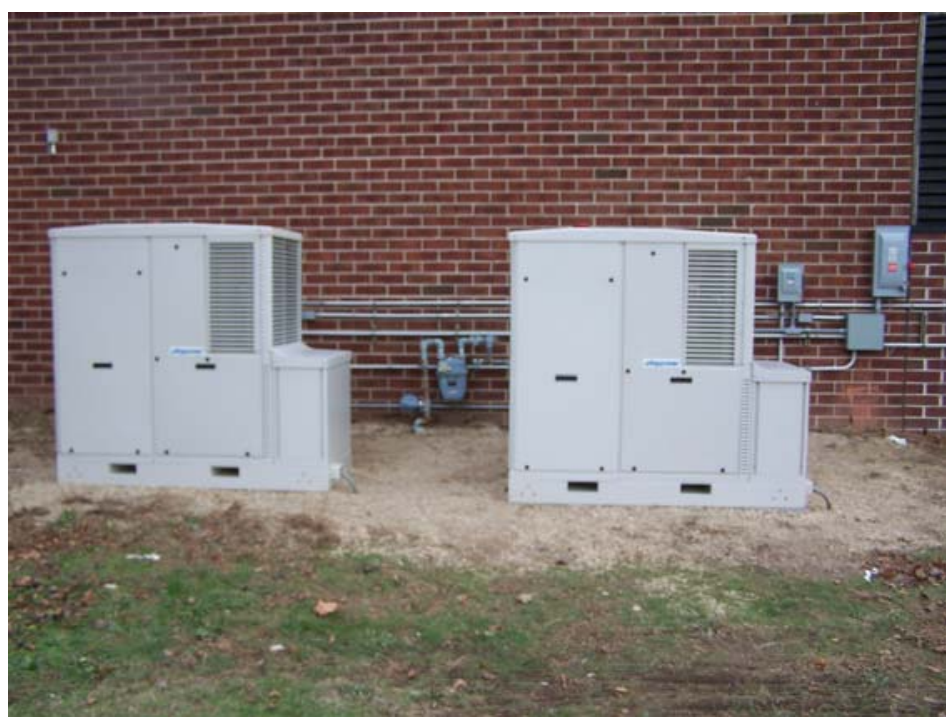

Figure 6: Fuel Cells at SUNY Farmingdale 
Table 5: Remote Sites Output for 20 Lorax 4.5 SU1 Fuel Cells

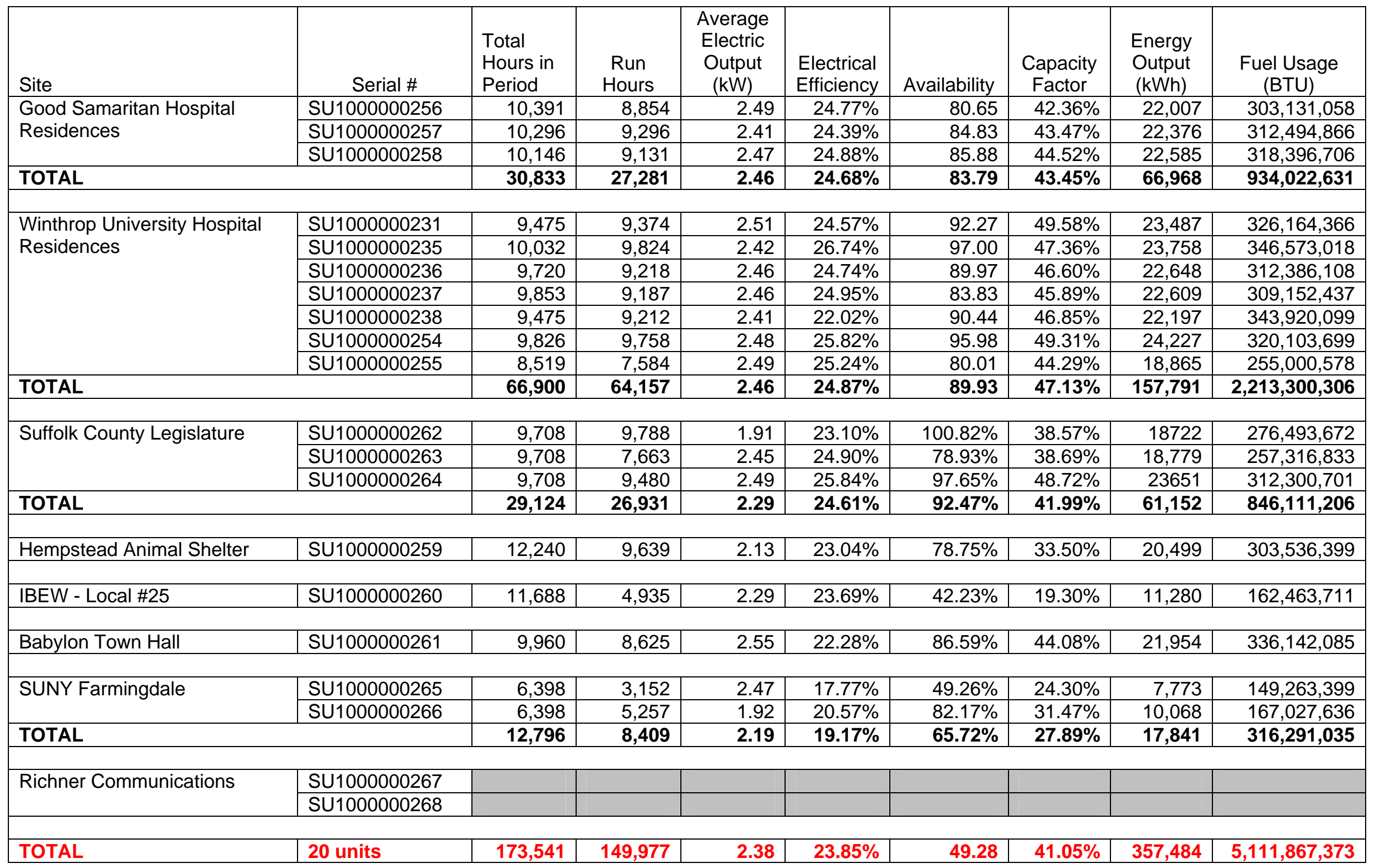


BTU meters were installed at several sites and monitored the thermal output of the fuel cells at these sites. Although this output varied for each site, the average thermal efficiency for all Remote Sites was $15.10 \%$ (Table 6). The thermal output of the unit at the Town of Hempstead's Animal Shelter was approximately 8 times greater than the average output for the residential sites at Good Samaritan Hospital and Winthrop-University Hospital. The average overall energy efficiency of the Remotes Sites was 38.95\%.

\begin{tabular}{|c|c|c|c|}
\hline Averages & Electrical Efficiency & Thermal Efficiency & Total Energy Efficiency \\
\hline $\begin{array}{c}\text { Remote Sites } \\
(18 \text { units })\end{array}$ & $23.85 \%$ & $15.10 \%$ & $38.95 \%$ \\
\hline
\end{tabular}

Table 6: Average Energy Efficiency of Remote Sites

Maintenance service calls for the fuel cell systems occurred in general every 3 to 4 months due to a shutdown. Services were considered as scheduled outages in any one or combination of the following scenarios:

- $\quad 12,000 \mathrm{kWh}$ of output service

- Telecommunication related service that did not relate to the electrical performance of the fuel cell system

- Follow-up to a previous service for an unplanned outage.

Table 7 summarizes the average maintenance requirements for all Remote Sites systems, excluding the 2 Richner Communications units. The figures included in the table below can also be applied to the 20 Farm fuel cell systems. Note that the numbers represent the average per unit per term of operation (12 to 18 months).

\begin{tabular}{|c|c|c|c|c|}
\hline & $\begin{array}{l}\text { Average Number } \\
\text { of Scheduled } \\
\text { Outages }\end{array}$ & $\begin{array}{l}\text { Average Number } \\
\text { of Unplanned } \\
\text { Outages }\end{array}$ & $\begin{array}{l}\text { Average Length } \\
\text { of Service Calls } \\
\text { (hours) }\end{array}$ & $\begin{array}{l}\text { Mean Time } \\
\text { Between Failure } \\
\text { (MBTF) } \\
\text { (hours) }\end{array}$ \\
\hline $\begin{array}{c}\text { Remote Sites } \\
\text { (18 units) }\end{array}$ & 1.92 & 6.96 & 6.04 & $\begin{array}{c}1,259 \\
(\sim 52 \text { days })\end{array}$ \\
\hline
\end{tabular}

Table 7: Average Maintenance Requirements

Overall, the 20 fuel cell systems tested at remote sites produced a total of $357,484 \mathrm{kWh}$ and cost a total of $\$ 1,649,116$ (Table 8 ) as of June 30,2006 ; resulting in an overall project cost of $\$ 4.61$ per $\mathrm{kWh}$. The combined energy output of the units at the Remote Sites accounted for an emission savings of $786 \mathrm{~kg}(1,733 \mathrm{lbs})$ of $\mathrm{SO}_{2}, 247 \mathrm{~kg}(545 \mathrm{lbs})$ of $\mathrm{NO}_{\mathrm{x}}$, and $42,266 \mathrm{~kg}(93,180 \mathrm{lbs})$ of $\mathrm{CO}_{2}$.

\begin{tabular}{|l|c|c|c|c|c|}
\hline Site & $\begin{array}{l}\text { Equipment/ } \\
\text { Installation }\end{array}$ & $\begin{array}{l}\text { Maintenance/ } \\
\text { Service }\end{array}$ & True Up & Decommissioning & Total \\
\hline $\begin{array}{l}\text { Remote Sites } \\
(20 \text { units })\end{array}$ & $\$ 1,460,000$ & $\$ 128,961$ & $\$ 7,191$ & $\$ 52,963$ & $\$ 1,649,116$ \\
\hline
\end{tabular}

Table 8: Remote Sites Costs 
LIPA, the equipment manufacturer, and the service contractor obtained significant operating knowledge through the installation, maintenance, and operation of this phase of the Remote Sites that included new applications with thermal output and critical load. The MBTF of this phase of Remote Sites being less than that of the previous phase (100 days) can be explained by the addition of recovered heat output outages. The Lorax 4.5 have performed with significantly greater availability than previous models. The addition of the heat recovery has increased the overall energy efficiency of the fuel cells further advancing them toward commercial viability. 


\section{CONCLUSION}

Since the inception of the Fuel Cell Program in 1999, one of LIPA's goals was to advance fuel cell technology as a clean, zero emission energy source that could reduce the current electric load on the transmission and distribution system. Indeed, LIPA's various demonstrations and testing of fuel cells led to significant technology advances such as increased efficiency and availability, decreased equipment size and costs.

This project resulted in great operational experience for LIPA, Plug Power, and the service contractor with the addition of the heat recovery and critical load applications. Experience and lessons learned led to quicker response time and repair time for the service contractor. This experience resulted in lower installation costs and maintenance costs per outage.

The 25 Lorax 4.5 fuel cells from the Farm and the 20 similar systems tested at Remote Sites produced a total of 1,585,093 $\mathrm{kWh}$. This clean energy production accounted for an emission savings of $3,485 \mathrm{~kg}(7,683 \mathrm{lbs})$ of $\mathrm{SO}_{2}, 1,097 \mathrm{~kg}(2,416 \mathrm{lbs})$ of $\mathrm{NO}_{\mathrm{x}}$ and 187,408 $\mathrm{kg}(413,163 \mathrm{lbs})$ of $\mathrm{CO}_{2}$.

For the period of this report, the project cost a total of approximately $\$ 3.8 \mathrm{M}$ including $\$ 154 \mathrm{~K}$ for the UL testing. $74 \%$ of that cost emanating from equipment and installation costs. Maintenance outlays accounted for $16 \%$ of the total cost; and Fuel, True Up, Decommissioning, and UL testing costs accounted for the remaining 10\%. The overall resulting project rate was $\$ 2.44 / \mathrm{kWh}$.

These phases of the Farm and Remote Sites deployment have advanced the commercialization of fuel cells toward commercial viability. Significant developments included the heat recovery increasing the energy efficiency of fuel cells as distributed generations, and the use of the technology as prime backup power to critical loads at moments of utility outages. It is expected that the industry will continue to improve the energy efficiency and to reduce the size and costs of fuel cell systems as distributed resources.

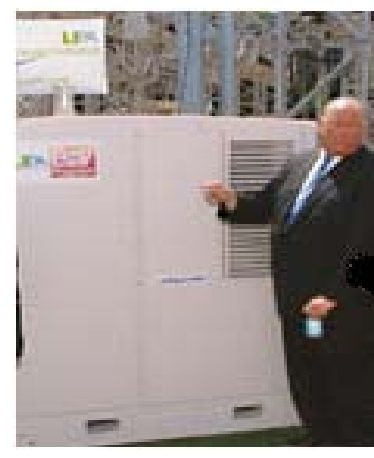

"Fuel cells hold great promise, as an environmentally friendly electric generating technology. We need to develop an understanding of how fuel cells can be integrated with our electric grid, and that's what this project will help identify."

- Richard Kessel, LIPA Chairman 


\section{REFERENCES}

LIPA Clean Energy Initiative, Annual Report 2000

LIPA Clean Energy Initiative, Annual Report 2001

LIPA Clean Energy Initiative, Annual Report 2002

LIPA Clean Energy Initiative, Annual Report 2003

LIPA Clean Energy Initiative, Annual Report 2004

Vincent Cassala, Personal Communication, July 2006

Herb Tracy, Personal Communication, July 11, 2006

Plug Power, LIPA Fuel Cell Demonstration Program

Underwriters Laboratories Inc., Phase 3 LIPA Fuel Cell Field Test Final Report 